\title{
Optimasi produksi hidrogel CTS-G-PAA/PVA sebagai adsorben menggunakan metode respon permukaan (RSM)
}

\section{Optimization of hydrogel CTS-G-PAA/PVA production as adsorbent using response surface methodology (RSM)}

\author{
Desak Gede Sri Andayani*, Nuri Astrini, Lik Anah \\ Loka Penelitian Teknologi Bersih, Lembaga Ilmu Pengetahuan Indonesia \\ Jl. Cisitu Sangkuriang, Gedung 50, Kampus LIPI, Bandung 40135 \\ *Penulis Korespondensi E-mail: desakgedesa@gmail.com
}

\author{
Diterima: 24 Oktober $2017 \quad$ Direvisi: 30 April $2018 \quad$ Disetujui: 14 Mei 2018
}

\begin{abstract}

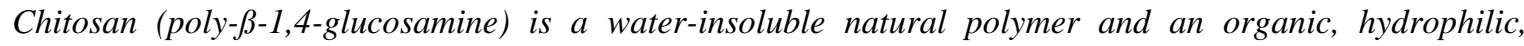
biocompatible and biodegradable solvent. The amino group in chitosan is more easily converted into cations in acidic solutions so it is strongly absorbing anions with electrostatic appeal, by adding and mixing synthetic polymers at the right ratio will improve the properties of chitosan as a biopolymer in dealing with environmental problems. The purpose of this study was to assess the capacity of water absorption and hydrogel formation in various chitosan variations on synthetic polymers. The experiment was carried out by surface response method using software Design Expert 6.06, 46 experiment variation, and eight center point with water absorption capacity $(\mathrm{g} / \mathrm{g})$ in response. The process was performed on a batch system, inert atmosphere, $1 \mathrm{~L}$ scale reactor with operating conditions was $90^{\circ} \mathrm{C}$ and processing time for 4 hours. Variations of biopolymers and synthetic polymers were as follows: chitosan (CTS): (0.15-1.2) g, acrylic acid (AA): (2-4.5) g, polyvinyl alcohol (PVA): (0.5-3) g, benzoyl peroxide (BPO): (0.03-0.13) g, methylene bis-acrylamide (MBA): (0.01-0.21) g. Data was analyzed using ANOVA at 95\% significant level. The water absorption capacity (WAC) for 24 hours was measured by gravimetric technique. The results showed that the variation of chitosan mixture as biopolymer with synthetic polymer influenced the water absorption capacity and hydrogel formation. The optimum water absorption capacity was $18.6(\mathrm{~g} / \mathrm{g})$ in the composition $(\mathrm{g})$ : CTS 0.67; AA 3.25; PVA 1.75; BPO 0.08 and MBA 0.11 . The formation of hydrogels is strongly influenced by the ratio of mixtures between natural polymers, monomers, synthetic polymers, initiators and crosslinking agents.
\end{abstract}

Keywords: chitosan, hydrogel, polymer, RSM, WAC.

\section{ABSTRAK}

Kitosan (poli-ß-1,4-glukosamin) merupakan polimer alami bersifat tidak larut dalam air dan pelarut organik, hidrofilik, biocompatible dan biodegradable. Gugus amino pada kitosan lebih mudah berubah menjadi kation dalam larutan asam sehingga sangat kuat menyerap anion dengan daya tarik elektrostatik. Dengan menambahkan dan mencampur polimer sintetik pada rasio yang tepat akan meningkatkan sifat-sifat kitosan sebagai biopolimer dalam menangani permasalahan lingkungan. Tujuan penelitian ini adalah untuk mengkaji kapasitas penyerapan air dan pembentukan hidrogel pada berbagai variasi kitosan terhadap polimer sintetis. Percobaan dilaksanakan dengan metode respon permukaan menggunakan perangkat lunak Design Expert 6,06, 46 variasi percobaan, dan delapan center point dengan kapasitas penyerapan air (g/g) sebagai respon. Proses dilakukan pada sistem batch, inert atmosphere, skala reaktor $1 \mathrm{~L}$ dengan kondisi operasi adalah suhu $90^{\circ} \mathrm{C}$ dan waktu proses selama 4 jam. Variasi biopolimer dan polimer sintetis sebagai berikut: kitosan (CTS): $(0,15-1,2) \mathrm{g}$, acrylic acid (AA): $(2-4,5) \mathrm{g}$, polyvinylalcohol (PVA): (0,5-3) g, benzoylperoxide (BPO): $(0,03-0,13) \mathrm{g}$, methylene bis-acrylamide (MBA): $(0,01-0,21)$ g. Data dianalisis menggunakan ANOVA pada taraf signifikan $95 \%$. Kapasitas penyerapan air (WAC) selama 24 jam diukur dengan teknik gravimetri. Hasil penelitian menunjukkan bahwa variasi campuran kitosan sebagai biopolimer dengan polimer sintetis mempengaruhi kapasitas penyerapan air dan pembentukan hidrogel. Kapasitas penyerapan air optimum adalah 18,6 (g/g) pada komposisi (g): CTS 0,67; AA 3,25; PVA 
1,75; BPO 0,08 dan MBA 0,11. Terbentuknya hidrogel sangat dipengaruhi oleh rasio campuran antara polimer alam, monomer, polimer sintetis, inisiator dan agen ikatan silang.

Kata kunci: hidrogel, kitosan, polimer, RSM, WAC.

\section{PENDAHULUAN}

Hidrogel atau superabsorbent polimer (SAP) adalah sistem multi-komponen yang terdiri dari jaringan silang tiga dimensi rantai polimer dan air atau polimer hidrofil, tidak larut dalam air, tahan tekanan serta mampu menyerap cairan sampai 200 kali berat material hidrogel (Chen et al., 2010; Ilić-Stojanović et al., 2014; Povea et al., 2011; Mahdavinia et al., 2006).

Kitosan sebagai sumber daya polisakarida yang terdiri dari d-glukosamin dan $\mathrm{N}$-asetil-dglucosamine akan membentuk hidrogel dengan mengikat silangkan gugus amina yang terdapat pada rantainya (Liu et al., 2011). Sebagai polimer alam, kitosan memiliki kelemahan dibandingkan dengan polimer sintetik yaitu dalam hal stabilitas daya serap yang lebih lemah dan mudah rusak dalam suasana asam serta suhu tinggi, sehingga perlu disubstitusi sifat fungsional unggul untuk menghasilkan hidrogel dengan sifat mekanis yang stabil (Hastuti et al., 2016).

Polivinil alkohol (PVA) adalah polimer sintetis yang bertindak sebagai interpenetrating agent (IPN-agent). Sifatnya yang hidrofil akan memperbaiki sifat gel kitosan dengan cara menurunkan waktu gelasi dan meningkatkan kekuatan mekanik (Liu et al., 2011).

Asam akrilat (AA) bertindak sebagai monomer, berfungsi untuk memperbaiki sifatsifat kimia dan fisika hidrogel dimana kombinasi kimiawi kitosan dan polimer berbasis akrillik akan meningkatkan penyerapan serta sifat kimia yang stabil (Anah et al., 2016). Hidrogel dengan asam akrilat (AA) mampu beradaptasi sesuai perubahan $\mathrm{pH}$ lingkungannya. Pada $\mathrm{pH}$ rendah hidrogel AA akan mengkerut (unswelling/shrinking) dan apabila $\mathrm{pH}$ bertambah tinggi hidrogel AA akan mengembang (swelling) (Aguilar et al., 2007). Penerapan AA di-graft kopolimerisasi kitosan untuk meningkatkan hidrofilitasnya untuk menghasilkan hidrogel berbahan dasar kitosan sebagai super absorbent berkualitas tinggi.

BPO (Benzoyl Peroxide) sebagai inisiator dalam pembentukan radikal, inisiasi, propagasi untuk inisiasi pembentukan radikal bebas, monomer-monomer menjadi polimer kemudian terminasi. BPO berfungsi untuk inisiasi polimerisasi grafting, kemudian dengan penambahan MBA terjadi ikatan silang untuk membentuk struktur tiga dimensi (Anah et al., 2016).

N,N-Metilen bis akrilamid (MBA) mengandung dua ikatan rangkap yang reaktif terdiri dari gugus amina bersifat tahan hidrolisis sebagai penyambung silang yang dapat tergabung ke dalam dua rantai yang berbeda saat polimerisasi terjadi ikatan silang hanya terjadi di beberapa tempat saja (tidak disepanjang rantai) (Garner et al., 1997). Dalam proses grafting polimerisasi diperlukan suatu agen pengikat silang agar terbentuk grafting dan ikatan silang untuk menghasilkan jejaring polimer yang dapat menyerap air. Diperlukan gugus aktif amina dalam suasana asam yang mampu berikatan dengan ion-ion logam dengan crosslinking (sambung silang) yang akan membentuk senyawa perantara untuk meningkatkan ketahanan kitosan terhadap asam. Selain meningkatkan kecepatan adsorpsi, ikatan silang (crosslink) berperan dalam menentukan elastisitas (ikatan deformasi plastis) dimana pada saat terjadi peregangan suatu material dapat kembali ke bentuk awal. Ikatan silang yang terjadi akan menyebabkan polimer yang terbentuk tidak dapat larut dalam air, akan tetapi kemampuan polimer untuk mengembang (swelling) turun selagi derajat ikatan silang meningkat (Bhattacharya et al., 2009; Astrini et al., 2016).

Penelitian ini bertujuan untuk optimasi kitosan yang digrafting oleh poly (AA)-co-PVA inisiator BPO serta MBA sebagai agen pengikat silang untuk menghasilkan hidrogel berkualitas tinggi menggunakan metode Response Surface Methods (Montgomery, 2009; Kaith et al., 2014).

\section{BAHAN DAN METODE \\ Bahan Penelitian}

Chitosan (CTS), acrylic acid (AA) dan aseton teknis, $N, N$-methylene bis acrylamide (MBA) dari Sigma-Aldrich, polivinil alkohol (PVA), benzoil peroksida (BPO), asam asetat, dan $\mathrm{NaOH}$ p.a. dari E-Merck, gas nitrogen $\left(\mathrm{N}_{2}\right)$ dan akuades.

\section{Peralatan Penelitian}

Reaktor gelas leher tiga volume $250 \mathrm{ml}$ yang dilengkapi dengan pengaduk mekanik, kondensor dan pemanas oil bath. 


\section{Metode Penelitian}

Proses polimerisasi untuk produksi hidrogel

Preparasi polimerisasi dilakukan dalam reaktor dengan melarutkan serbuk CTS dalam larutan asam asetat $1 \%(\mathrm{v} / \mathrm{v})$, sambil dilakukan pengusiran oksigen dengan mengalirkan gas $\mathrm{N}_{2}$ ke dalam reaktor. Inisiator BPO dilarutkan dalam akuades kemudian dicampurkan dengan larutan CTS di dalam reaktor. Monomer vinil AA yang telah ditambah $\mathrm{NaOH}$ dimasukkan ke dalam reaktor, dilanjutkan dengan penambahan PVA, MBA sebagai agen ikatan silang dilarutkan dalam akuades dimasukkan ke dalam reaktor. Proses polimerisasi dilaksanakan pada suhu $90^{\circ} \mathrm{C}, 270$ rpm selama 4 jam. Setelah proses selesai, larutan dinetralkan dengan menambahkan $6 \mathrm{~N}$ larutan $\mathrm{NaOH}$. Kemudian dilakukan pencucian menggunakan larutan aseton lalu dikeringkan ke dalam oven pada suhu $60^{\circ} \mathrm{C}$ sampai beratnya konstan.

Penentuan water absorbance capacity (WAC) (g/g) melalui uji swelling

Uji swelling hidrogel dilakukan dengan menimbang contoh sebanyak $0,2 \mathrm{~g}$ yang diisikan ke dalam kantong nilon yang telah ditimbang sebelumnya. Kemudian melakukan perendaman sampel selama 24 jam pada suhu ruang. Rasio swelling dihitung menggunakan persamaan sebagai berikut:

Rasio swelling $(\mathrm{g} / \mathrm{g})=[(\mathrm{Ws}-\mathrm{Wd}) /(\mathrm{Wd})] \times 100$

dengan:

Ws $=$ Berat contoh yang mengembang (swollen)

$\mathrm{Wd}=$ Berat contoh kering sebelum perendaman

\section{HASIL DAN PEMBAHASAN}

Strategi desain eksperimental berurutan berhasil meningkatkan kapasitas swelling hidrogel berbasis kitosan dengan dua kali lipat menjadi 200\%. Hidrogel sangat sensitif terhadap $\mathrm{pH}$ dan hasil terbaiknya diperoleh mendekati $\mathrm{pH}$ netral dengan inisiator optimum untuk memaksimalkan nilai swelling. Parameter optimal lainnya adalah rasio monomer. Akhirnya eksperimen validasi menunjukkan keefektifan model (Kaith et al., 2014).

Penelitian ini menggunakan Central Composite Design (CCD) yang terdiri dari 46 tempuhan termasuk 8 titik tengah (center point). Pada optimasi menggunakan CCD maka akan terdapat 8 titik pengamatan untuk tiap faktor yang ditinjau $(-\alpha),(-),(0),(+)$ dan $(+\alpha)$. Nilai-nilai tersebut untuk penelitian ini untuk masing-masing variabel CTS, AA, PVA, MBA, BPO disajikan dalam Tabel 2.

Variabel yang digunakan untuk optimasi pada metode RSM ini adalah CTS, AA, PVA, BPO dan MBA yang berturut-turut merupakan polimer alam, monomer, polimer sintetis yang larut air, inisiator dan agen pengikat silang yang sangat mempengaruhi terbentuknya hidrogel yang dihasilkan. Variabel tersebut diatas memiliki gugus hidrofil seperti $-\mathrm{OH},-\mathrm{COOH}, \mathrm{COO}^{-}$, dan $-\mathrm{CONH}_{2}$ yang terikat pada polimer digunakan untuk membentuk ikatan tiga dimensi pada hidrogel. Penelitian ini menggunakan rentang CTS $(0,15-1,2) \mathrm{g}$, AA $(2-4,5) \mathrm{g}$, PVA $(0,5-3) \mathrm{g}$, BPO $(0,03-0,13) \mathrm{g}$ dan MBA $(0,01-0,21) \mathrm{g}$.

Hasil penelitian untuk 46 tempuhan secara acak disajikan dalam Tabel 3. Dari 46 tempuhan tersebut, 8 tempuhan merupakan titik tengah (center point) untuk pemeriksaan reducibility dan estimasi kesalahan percobaan. WAC sebagai respon disajikan dalam kolom paling kanan.

Analisis varian (ANOVA) untuk hasil percobaan disajikan dalam Tabel 4 dan dilakukan dengan bantuan perangkat lunak Design Expert versi 6,0,6, dari analisis fit summary maka model yang disarankan dari hasil data tersebut adalah model linier.

Tabel 4, menghasilkan nilai $\mathrm{F}$ untuk model 4,13 yang menunjukkan bahwa model signifikan pada tingkat kepercayaan $95 \%$. Sedangkan nilai $\mathrm{p}$ $($ Prob $>F)$ model adalah kurang dari 0,05 $(<0,0039)$ yang mengindikasikan bahwa secara keseluruhan variabel model signifikan. Hal ini berarti bahwa variabel dalam model mempunyai efek yang signifikan terhadap respon. Pada analisis di atas, variabel B merupakan variabel yang signifikan dengan nilai $\mathrm{p}($ Prob $>F)$ kurang dari 0,05. Sedangkan A, C, D, E tidak signifikan terhadap respon WAC, namun tetap diikutsertakan dalam model untuk mendapatkan model hirarki. Model persamaan matematika yang dihasilkan dari analisis data pada Tabel 4 disajikan dalam persamaan 2 . 
Tabel 1. Tempuhan optimasi produksi hidrogel.

\begin{tabular}{|c|c|c|c|c|c|c|}
\hline Tempuhan & $\begin{array}{c}\text { CTS } \\
(\mathrm{g})\end{array}$ & $\begin{array}{l}\text { AA } \\
\text { (g) }\end{array}$ & $\begin{array}{c}\text { PVA } \\
\text { (g) }\end{array}$ & $\begin{array}{c}\text { BPO } \\
(\mathrm{g})\end{array}$ & $\begin{array}{c}\text { MBA } \\
(\mathrm{g})\end{array}$ & Respon \\
\hline 1 & 1,2 & 4,5 & 3 & 0,03 & 0,01 & \\
\hline 2 & 0,15 & 2 & 3 & 0,13 & 0,13 & \\
\hline 3 & 1,2 & 4,5 & 3 & 0,13 & 0,01 & \\
\hline 4 & 1,2 & 4,5 & 3 & 0,13 & 0,13 & \\
\hline 5 & 0 & 3,25 & 1,75 & 0,08 & 0,07 & \\
\hline 6 & 0,67 & 3,25 & 1,75 & 0,08 & 0,07 & \\
\hline 7 & 0,67 & 3,25 & 1,75 & 0,08 & 0 & \\
\hline 8 & 0,67 & 3,25 & 1,75 & 0,08 & 0,07 & \\
\hline 9 & 0,675 & 3,25 & 4,72 & 0,08 & 0,07 & \\
\hline 10 & 0,67 & 3,25 & 1,75 & 0,08 & 0,07 & \\
\hline 11 & 0,15 & 2 & 3 & 0,13 & 0,01 & \\
\hline 12 & 0,67 & 3,25 & 1,75 & 0,08 & 0,21 & \\
\hline 13 & 0,15 & 4,5 & 3 & 0,03 & 0,13 & \\
\hline 14 & 0,15 & 2 & 3 & 0,03 & 0,01 & \\
\hline 15 & 0,15 & 2 & 0,5 & 0,13 & 0,13 & WAC $(\mathrm{g} / \mathrm{g})$ \\
\hline 16 & 0,67 & 0,28 & 1,75 & 0,08 & 0,07 & (24 jam) \\
\hline 17 & 1,92 & 3,25 & 1,75 & 0,08 & 0,07 & \\
\hline 18 & 0,67 & 3,25 & 1,75 & 0,08 & 0,07 & \\
\hline 19 & 1,2 & 2 & 0,5 & 0,13 & 0,13 & \\
\hline 20 & 1,2 & 2 & 3 & 0,03 & 0,13 & \\
\hline 21 & 1,2 & 2 & 0,5 & 0,13 & 0,01 & \\
\hline 22 & 1,2 & 4,5 & 0,5 & 0,13 & 0,13 & \\
\hline 23 & 1,2 & 4,5 & 3 & 0,03 & 0,13 & \\
\hline 24 & 1,2 & 4,5 & 0,5 & 0,03 & 0,01 & \\
\hline 25 & 1,2 & 2 & 0,5 & 0,03 & 0,01 & \\
\hline 26 & 0,67 & 3,25 & 1,75 & 0,2 & 0,07 & \\
\hline 27 & 1,2 & 4,5 & 0,5 & 0,03 & 0,13 & \\
\hline 28 & 0,15 & 4,5 & 0,5 & 0,03 & 0,01 & \\
\hline 29 & 0,15 & 2 & 0,5 & 0,13 & 0,01 & \\
\hline 30 & 0,67 & 3,25 & 1,75 & 0,08 & 0,07 & \\
\hline 31 & 1,2 & 4,5 & 0,5 & 0,13 & 0,01 & \\
\hline 32 & 0,67 & 3,25 & 1,75 & 0,08 & 0,07 & \\
\hline 33 & 0,15 & 4,5 & 3 & 0,03 & 0,01 & \\
\hline 34 & 0,15 & 2 & 3 & 0,03 & 0,13 & \\
\hline 35 & 1,2 & 2 & 3 & 0,13 & 0,13 & \\
\hline 36 & 0,15 & 4,5 & 3 & 0,13 & 0,01 & \\
\hline 37 & 0,67 & 3,25 & 1,75 & $-1,4 \mathrm{E}-17$ & 0,07 & \\
\hline 38 & 0,67 & 3,25 & 1,75 & 0,08 & 0,07 & \\
\hline 39 & 1,2 & 2 & 3 & 0,13 & 0,01 & \\
\hline 40 & 0,15 & 2 & 0,5 & 0,03 & 0,13 & \\
\hline 41 & 0,67 & 3,25 & 1,75 & 0,08 & 0,07 & \\
\hline 42 & 1,2 & 2 & 0,5 & 0,03 & 0,13 & \\
\hline 43 & 0,15 & 4,5 & 0,5 & 0,13 & 0,13 & \\
\hline 44 & 1,2 & 2 & 3 & 0,03 & 0,01 & \\
\hline 45 & 0,15 & 2 & 0,5 & 0,03 & 0,01 & \\
\hline 46 & 0,67 & 3,25 & $-2,2 \mathrm{E}-16$ & 0,08 & 0,07 & \\
\hline
\end{tabular}


Tabel 2. Central Composite Design (CCD).

\begin{tabular}{cccccc}
\hline Variabel & $(-)$ & $(+)$ & $(0)$ & $(-\alpha)$ & $(+\alpha)$ \\
\hline CTS & 0,15 & 1,2 & 0,675 & 0 & 1,92 \\
AA & 2 & 4,5 & 3,25 & 0,28 & 4,5 \\
PVA & 0,5 & 3 & 1,75 & $-2,2 \mathrm{E}-16$ & 4,72 \\
BPO & 0,03 & 0,13 & 0,08 & $-1,4 \mathrm{E}-17$ & 0,13 \\
MBA & 0,01 & 0,21 & 0,11 & 0 & 0,13 \\
\hline
\end{tabular}

Tabel 3. Optimasi WAC dengan metode RSM.

\begin{tabular}{|c|c|c|c|c|c|c|}
\hline Tempuhan & CTS (g) & AA $(g)$ & PVA (g) & $\mathrm{BPO}(\mathrm{g})$ & $\operatorname{MBA}(\mathrm{g})$ & WAC (24 jam) (g/g) \\
\hline 1 & 1,2 & 4,5 & 3 & 0,03 & 0,01 & 9 \\
\hline 2 & 0,15 & 2 & 3 & 0,13 & 0,13 & 14,2 \\
\hline 3 & 1,2 & 4,5 & 3 & 0,13 & 0,01 & 18,5 \\
\hline 4 & 1,2 & 4,5 & 3 & 0,13 & 0,13 & 15,8 \\
\hline 5 & 0 & 3,25 & 1,75 & 0,08 & 0,07 & 0 \\
\hline 6 & 0,67 & 3,25 & 1,75 & 0,08 & 0,07 & 13 \\
\hline 7 & 0,67 & 3,25 & 1,75 & 0,08 & 0 & 0 \\
\hline 8 & 0,67 & 3,25 & 1,75 & 0,08 & 0,07 & 18,6 \\
\hline 9 & 0,675 & 3,25 & 4,72 & 0,08 & 0,07 & 12,5 \\
\hline 10 & 0,67 & 3,25 & 1,75 & 0,08 & 0,07 & 9,3 \\
\hline 11 & 0,15 & 2 & 3 & 0,13 & 0,01 & 8,4 \\
\hline 12 & 0,67 & 3,25 & 1,75 & 0,08 & 0,21 & 3,9 \\
\hline 13 & 0,15 & 4,5 & 3 & 0,03 & 0,13 & 3 \\
\hline 14 & 0,15 & 2 & 3 & 0,03 & 0,01 & 2,6 \\
\hline 15 & 0,15 & 2 & 0,5 & 0,13 & 0,13 & 3 \\
\hline 16 & 0,67 & 0,28 & 1,75 & 0,08 & 0,07 & 1,7 \\
\hline 17 & 1,92 & 3,25 & 1,75 & 0,08 & 0,07 & 7,6 \\
\hline 18 & 0,67 & 3,25 & 1,75 & 0,08 & 0,07 & 6,9 \\
\hline 19 & 1,2 & 2 & 0,5 & 0,13 & 0,13 & 5,4 \\
\hline 20 & 1,2 & 2 & 3 & 0,03 & 0,13 & 5,1 \\
\hline 21 & 1,2 & 2 & 0,5 & 0,13 & 0,01 & 4 \\
\hline 22 & 1,2 & 4,5 & 0,5 & 0,13 & 0,13 & 10,5 \\
\hline 23 & 1,2 & 4,5 & 3 & 0,03 & 0,13 & 4 \\
\hline 24 & 1,2 & 4,5 & 0,5 & 0,03 & 0,01 & 7 \\
\hline 25 & 1,2 & 2 & 0,5 & 0,03 & 0,01 & 9,7 \\
\hline 26 & 0,67 & 3,25 & 1,75 & 0,2 & 0,07 & 7,7 \\
\hline 27 & 1,2 & 4,5 & 0,5 & 0,03 & 0,13 & 5,7 \\
\hline 28 & 0,15 & 4,5 & 0,5 & 0,03 & 0,01 & 10,85 \\
\hline 29 & 0,15 & 2 & 0,5 & 0,13 & 0,01 & 4,4 \\
\hline 30 & 0,67 & 3,25 & 1,75 & 0,08 & 0,07 & 5,6 \\
\hline 31 & 1,2 & 4,5 & 0,5 & 0,13 & 0,01 & 0 \\
\hline 32 & 0,67 & 3,25 & 1,75 & 0,08 & 0,07 & 8,4 \\
\hline 33 & 0,15 & 4,5 & 3 & 0,03 & 0,01 & 27,1 \\
\hline 34 & 0,15 & 2 & 3 & 0,03 & 0,13 & 4,6 \\
\hline 35 & 1,2 & 2 & 3 & 0,13 & 0,13 & 0 \\
\hline 36 & 0,15 & 4,5 & 3 & 0,13 & 0,01 & 0 \\
\hline 37 & 0,67 & 3,25 & 1,75 & $-1,4 \mathrm{E}-17$ & 0,07 & 0 \\
\hline 38 & 0,67 & 3,25 & 1,75 & 0,08 & 0,07 & 7,6 \\
\hline 39 & 1,2 & 2 & 3 & 0,13 & 0,01 & 3,5 \\
\hline 40 & 0,15 & 2 & 0,5 & 0,03 & 0,13 & 9,6 \\
\hline 41 & 0,67 & 3,25 & 1,75 & 0,08 & 0,07 & 6,5 \\
\hline 42 & 1,2 & 2 & 0,5 & 0,03 & 0,13 & 5,89 \\
\hline 43 & 0,15 & 4,5 & 0,5 & 0,13 & 0,13 & 47,3 \\
\hline 44 & 1,2 & 2 & 3 & 0,03 & 0,01 & 5,8 \\
\hline 45 & 0,15 & 2 & 0,5 & 0,03 & 0,01 & 2,1 \\
\hline 46 & 0,67 & 3,25 & $-2,2 \mathrm{E}-16$ & 0,08 & 0,07 & 0 \\
\hline
\end{tabular}


Tabel 4. Analisis varian (ANOVA) untuk model linier dengan respon WAC.

\begin{tabular}{cccccc}
\hline Variabel & Sum of Squares & DF & Mean Square & $F$ Value & Prob $>F$ \\
\hline Model & 2608,14 & 5 & 521,63 & 4,13 & $<0,0039$ \\
A & 364,34 & 1 & 364,34 & 2,88 & 0,0970 \\
B & 1793,77 & 1 & 1793,77 & 14,19 & 0,0005 \\
C & 46,69 & 1 & 46,69 & 0,37 & 0,5467 \\
D & 234,31 & 1 & 234,31 & 1,85 & 0,1806 \\
E & 170,42 & 1 & 170,42 & 1,35 & 0,2522 \\
Residual & 5309,45 & 42 & 126,42 & & \\
\hline
\end{tabular}

$\mathrm{WAC}=11,56-3,14 \mathrm{~A}+6,62 \mathrm{~B}-1,12 \mathrm{C}+2,48 \mathrm{D}+3,59 \mathrm{E}$

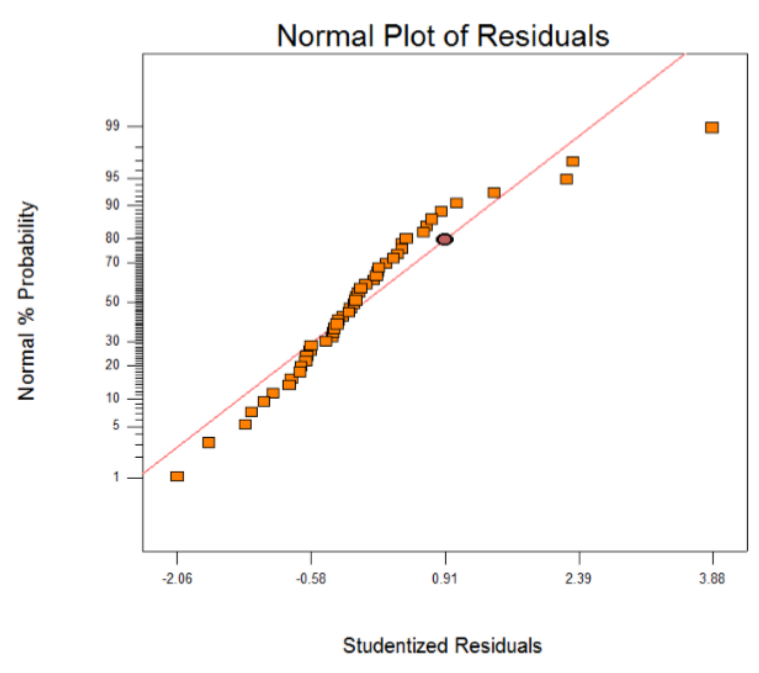

Gambar 1. Kurva probabilitas normal untuk respon WAC.

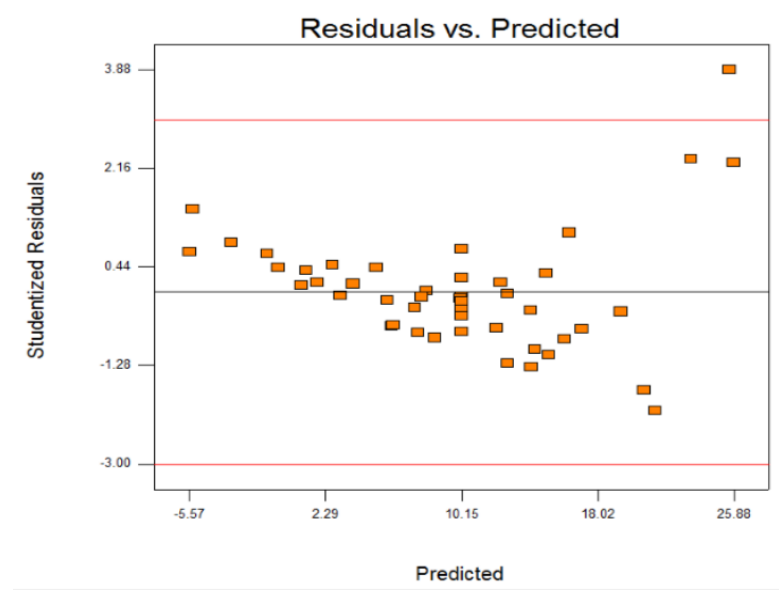

Gambar 2. Residual dan prediksi respon untuk WAC.

Model yang dihasilkan perlu diperiksa kecukupan modelnya meliputi normal probability plot dan residual plot. Gambar 1 merupakan normal probability plot dari residual dan memperlihatkan bahwa residual secara umum berada pada garis lurus yang berarti kesalahan terdistribusi secara normal. Sedangkan Gambar 2 menunjukkan bahwa residual tidak menunjukkan pola tertentu (acak). Dengan demikian, dari pengujian kecukupan model tersebut maka model menjadi akurat untuk memprediksi produksi hidrogel dengan tinjauan variabel CTS, AA, PVA, BPO, dan MBA. Pengaruh CTS, AA, PVA, BPO dan MBA terhadap WAC dapat terlihat dari profil kurva tiga dimensi seperti disajikan dalam Gambar 3, 4, 5, 6 dan 7.

Pengaruh dari CTS (g) dan AA (g) terhadap WAC pada PVA, BPO, MBA $(1,75 ; 0,08 ; 0,11) \mathrm{g}$ dapat dilihat jelas pada Gambar 3. Semakin meningkat jumlah CTS (polimer alam) sampai optimum 0,67 gram menyebabkan semakin menurunnya nilai WAC. Hal ini terjadi karena adanya ikatan silang. Ikatan silang dalam hidrogel ini akan menurunkan fleksibilitas. Meningkatnya rasio ikatan silang akan menurunkan WAC karena konsentrasi ikatan silang yang lebih tinggi menyebabkan titik silang yang lebih banyak dalam jaringan polimer sehingga menurunkan ruang bebas antara rantai polimer akibatnya struktur kaku jaringan polimer yang sangat berikatan silang meningkat dan daya serap air menurun (Liu et al., 2011).

Pengaruh dari AA (g) dan CTS (g) terhadap WAC pada PVA, BPO, MBA $(1,75 ; 0,08 ; 0,11) \mathrm{g}$ dapat dilihat jelas pada Gambar 4 semakin meningkat jumlah AA (monomer) sampai optimum 3,25 gram menyebabkan semakin meningkatnya nilai WAC. Sebagai rasio berat AA untuk CTS meningkat, semakin banyak molekul monomer yang tersedia di sekitar situs propaganda rantai CTS makro radial bisa jadi dicangkokkan ke tulang punggung CTS, yang meningkatkan efisiensi pencangkokan peningkatan hidrofilisitas yang super absorben, kemudian menghasilkan peningkatan daya serap air. Berat molekul polimer yang dihasilkan mencangkok rantai PAA ke tulang punggung CTS meningkat dengan meningkatnya rasio berat AA terhadap CTS, yang menyebabkan membaiknya penyerapan air (Liu et al., 2011). 
Pengaruh dari PVA (g) dan CTS (g) terhadap WAC pada PVA, BPO, MBA $(1,75$; $0,08 ; 0,11) \mathrm{g}$ dapat dilihat jelas pada Gambar 5, peningkatan jumlah PVA sampai optimum 1,75 gram sebagai polimer sintetis tidak berpengaruh terhadap peningkatan nilai WAC.

Peningkatan rasio PVA menyebabkan daya serap air menurun. Perilaku ini disebabkan oleh fakta bahwa kenaikan awal dalam kandungan PVA menyebabkan peningkatan hidrofilisitas semi-IPN superabsorbent hydrogel, dan molekul PVA dapat bertindak sebagai dispersan selama proses polimerisasi yang meningkatkan dispersi reaktan dan memperbaiki struktur jaringan yang super absorbent semi-IPN.

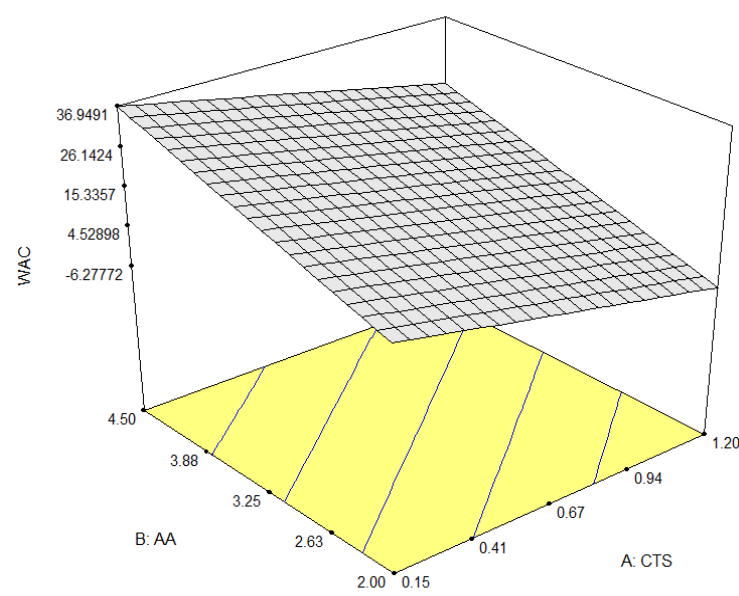

Gambar 3. Grafik tiga dimensi hubungan antara CTS dan AA pada PVA, BPO dan MBA $(1,75$; $0,08 ; 0,11) \mathrm{g}$.

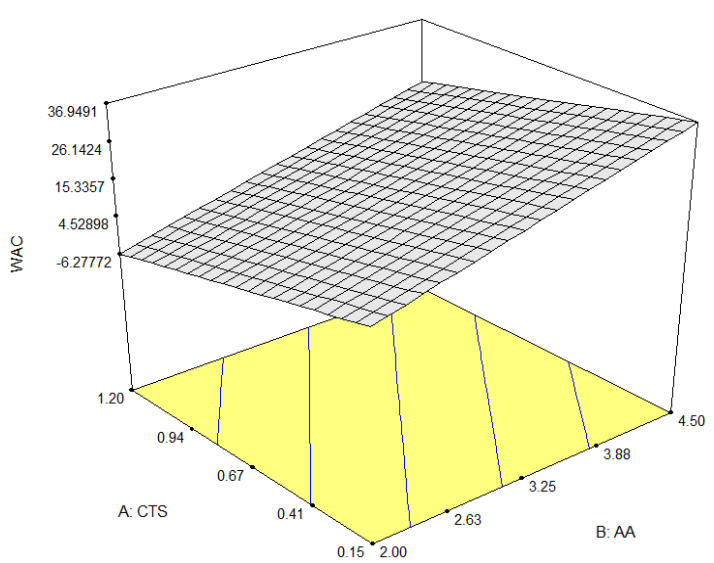

Gambar 4. Grafik tiga dimensi hubungan antara AA dan CTS pada PVA, BPO dan MBA $(1,75$; $0,08 ; 0,11) \mathrm{g}$.

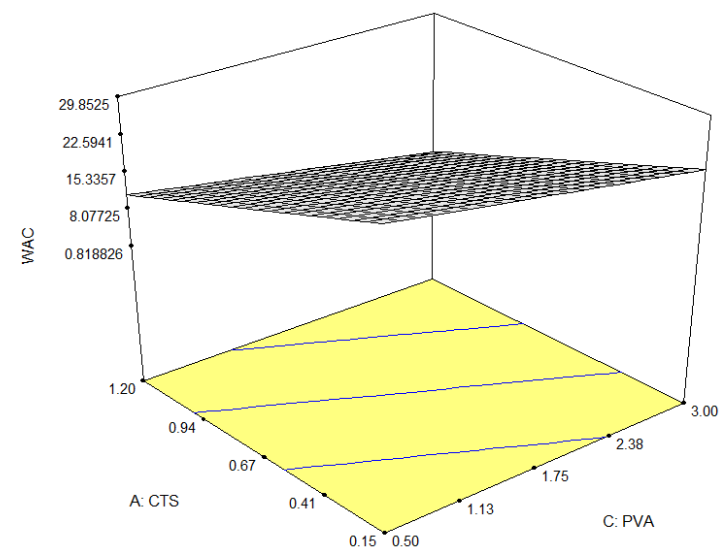

Gambar 5. Grafik tiga dimensi hubungan antara PVA dan CTS pada AA, BPO dan MBA $(3,25$; $0,08 ; 0,11) \mathrm{g}$.

Peningkatan jumlah silang fisik akibat keterikatan antara PVA dan CTS- $g$-PAA dapat mengakibatkan berkurangnya daya serap air (Liu et al., 2011).

Pengaruh dari BPO (g) dan CTS (g) terhadap WAC pada AA, PVA, MBA $(3,25 ; 1,75$; $0,11) \mathrm{g}$ dapat dilihat jelas pada Gambar 6, peningkatan jumlah BPO optimum 0,08 gram sebagai inisiator akan meningkatkan nilai WAC. Suhu tinggi $\left(90^{\circ} \mathrm{C}\right)$ dan $\mathrm{pH}$ netral (7) membantu meningkatkan terjadinya tumbukan antar inisiator BPO dengan CTS sehingga radikal kitosan yang terbentuk ikut meningkat dan berpengaruh pada meningkatnya kopolimerisasi cangkok PAA pada batang tubuh kitosan yang akhirnya berdampak pada meningkatnya WAC dari hidrogel CTS-gPAA (Anah et al., 2016).

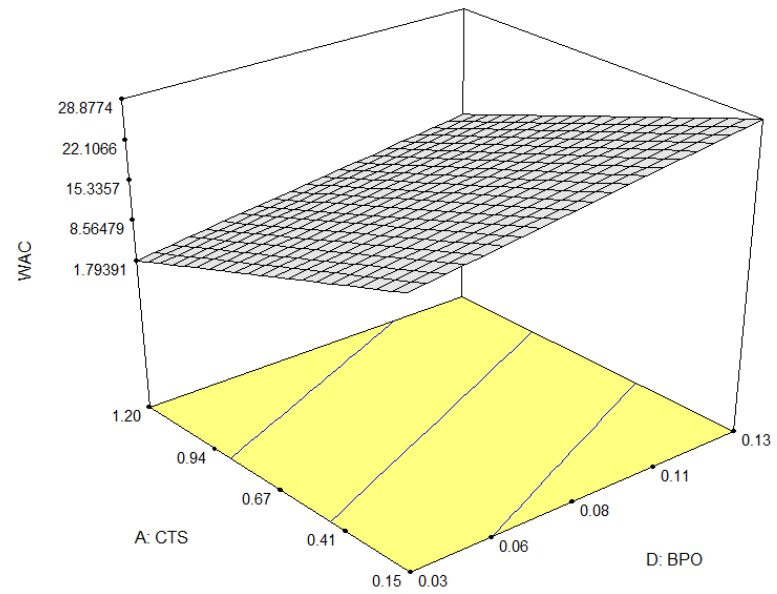

Gambar 6. Grafik tiga dimensi hubungan antara BPO dan CTS pada AA, PVA, dan MBA $(3,25$; $1,75 ; 0,11) \mathrm{g}$. 
Tabel 5. Validasi model RSM antara hasil prediksi dan percobaan.

\begin{tabular}{ccccccc}
\hline CTS $(\mathrm{g})$ & AA $(\mathrm{g})$ & PVA $(\mathrm{g})$ & BPO $(\mathrm{g})$ & MBA $(\mathrm{g})$ & $\begin{array}{c}\text { WAC }(\mathrm{g} / \mathrm{g})- \\
\text { prediksi }\end{array}$ & $\begin{array}{c}\text { WAC }(\mathrm{g} / \mathrm{g})- \\
\text { hasil } \\
\text { validasi }\end{array}$ \\
\hline 0,67 & 3,25 & 1,75 & 0,08 & 0,11 & 15,68 & 18,60 \\
\hline
\end{tabular}

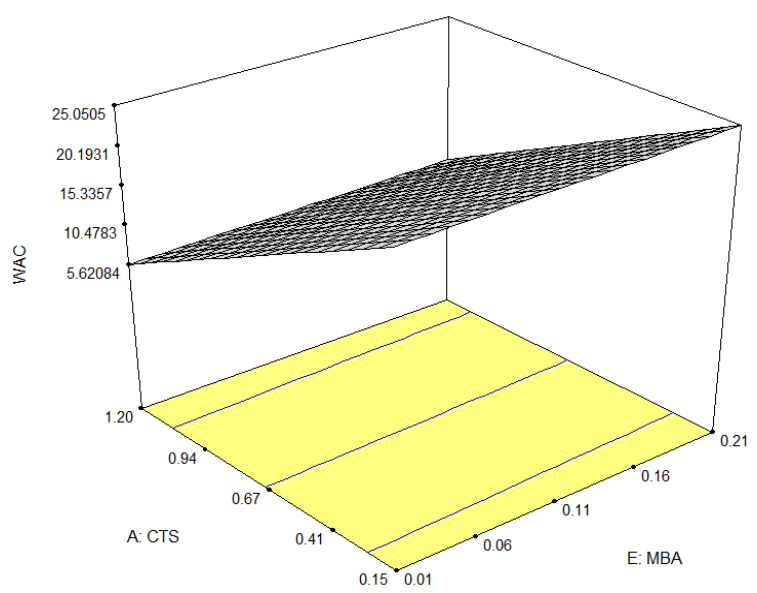

Gambar 7. Grafik tiga dimensi hubungan antara MBA dan CTS pada AA, PVA dan BPO $(3,25$; $1,75 ; 0,08) \mathrm{g}$.

Pengaruh dari MBA (g) dan CTS (g) terhadap WAC pada PVA, BPO, MBA $(1,75$; $0,08 ; 0,11) \mathrm{g}$ dapat dilihat jelas pada Gambar 7 , peningkatan jumlah MBA optimum pada 0,11 gram sebagai ikatan silang akan meningkatkan nilai WAC. Pemeriksaan keakuratan kondisi optimum yang dihasilkan oleh perangkat lunak Design Expert dilakukan dengan melakukan validasi. Validasi model dilakukan berdasarkan salah satu penyelesaian optimasi seperti disajikan dalam Tabel 5. Hasil validasi menunjukkan bahwa hasil prediksi dan hasil percobaan tidak berbeda jauh sehingga model tervalidasi.

\section{KESIMPULAN}

Pembentukan hidrogel sebagai super absorben sangat dipengaruhi oleh komposisi campuran variabel CTS, AA, PVA, BPO dan MBA pada rasio optimum $(0,67 ; 3,25 ; 1,75 ; 0,08$; $0,11)$ g. Peningkatan penambahan CTS (g) sebagai polimer alam diatas nilai optimum akan menyebabkan menurunnya WAC dan berbanding terbalik dengan peningkatan jumlah AA, BPO dan MBA sebagai monomer, inisiator dan agen ikatan silang. Sedangkan penambahan PVA sebagai polimer sintetis dalam campuran tidak terlalu berpengaruh terhadap peningkatan WAC.

\section{UCAPAN TERIMAKASIH}

Penelitian ini didanai oleh Program Mandiri LIPI 2017.

\section{DAFTAR PUSTAKA}

Anah, L., Astrini, N., \& Haryono, A. (2016). Pengaruh suhu reaksi pada polimerisasi hidrogel berbasis kitosan. Jurnal Sains Materi Indonesia, 17(2), 63-68.

Aguilar, M. R., Elvira, C., Gallardo, A., Vazquez, B., \& Roman, J. S. (2007). Smart polymer and their applications as biomaterials. Topics in Tissue Engineering, 3, 1-27.

Astrini, N., Anah, L., \& Haryono, A. (2016). Pengaruh MBA pada pembuatan superabsorben hidrogel berbasis selulosa terhadap sifat penyerapan air. Jurnal Kimia Kemasan, 38(1), 15-20. http://doi.org/10.24817/jkk.v38i1.1974

Bhattacharya, A., Ravlins, J. W., \& Ray, P. (2009). Polymer grafting and crosslinking. New York, USA: John Wiley \& Sons Inc.

Chen, J., Liu, M., Liu, H., Ma, L., Gao, C., Zhu, S., \& Zhang, S. (2010). Synthesis and properties of thermo- and $\mathrm{pH}$-sensitive poly (diallyldimethylammonium chloride)/poly (N,Ndiethylacrylamide) semi-IPN hydrogel. Chemical Engineering Journal, 159(1-3), 247-256. https://doi.org/10.1016/j.cej.2010.02.034

Garner, C. M., Nething, M., \& Nguyen, P. (1997). The synthesis of a superabsorbent polymer. Journal of Chemical Education, 74(1), 95-96. http://doi.org/10.1021/ed074p95

Hastuti, B., Masykur, A., \& Hadi, S. (2016). Modification of chitosan by swelling and crosslinking using epichlorohydrin as heavy metal $\mathrm{Cr}(\mathrm{VI})$ adsorbent in batik industry wastes. IOP Conference Series: Material Science and Engineering, $\quad 107, \quad 1-9$. https://doi.org/10.1088/1757-899X/107/1/012020

Ilić-Stojanović, S. S., Nikolić, L. B., Nikolić, V. D., Petrović, S. D., Zdravković, A. S. \& Stamenković, J. V. (2014). The effect of the cross-linker content on the swelling properties of intelligent gels. Savremene tehnologije, 3 (2), 1015. https://doi.org/10.5937/savteh1402010I

Kaith, B. S., Sharma, R., Kalia, S., \& Bhatti, M. S. (2014). Response surface methodology and optimized synthesis of guar gum-based hydrogels with enhanced swelling capacity. $R S C$ Advances, 40339-40344. http://doi.org/10.1039/C4RA05300A 
Liu, J. Wang, W., \& Wang, A. (2011). Synthesis, characterization, and swelling behaviors of chitosan-g-poly(acrylic acid)/poly(vinyl alcohol) semi-IPN superabsorbent hydrogels. Polymers Advanced Technology, 22 (5), 627-634. https://doi.org/10.1002/pat.1558

Mahdavinia, G. R., Pourjavadi, A., \& ZohuriaanMehr, M. J. (2006). A convenient one-step preparation of chitosan-poly (sodium acrylateco-acrylamide) hydrogel hybrids with superswelling properties. Journal of Applied Polymer Science, 99(4), 1615-1619. https://doi.org/10.1002/app.22521
Montgomery, D. C. (2009). Design and analysis of experiments $\left(5^{\text {th }}\right.$ ed.). New York, USA: John Wiley \& Sons Inc.

Povea, M. B., Monal, W. A., Rodriguez, J. V. C., Pat, A. M., Rivero, N. B., \& Covas, C. P. (2011). Interpenetrated chitosan-poly (acrylic acid-coacrylamide) hydrogels. Synthesis, characterization and sustained protein release studies. Material Sciences and Applications, 2, 509-520. http://doi.org/10.4236/msa.2011.26069 
